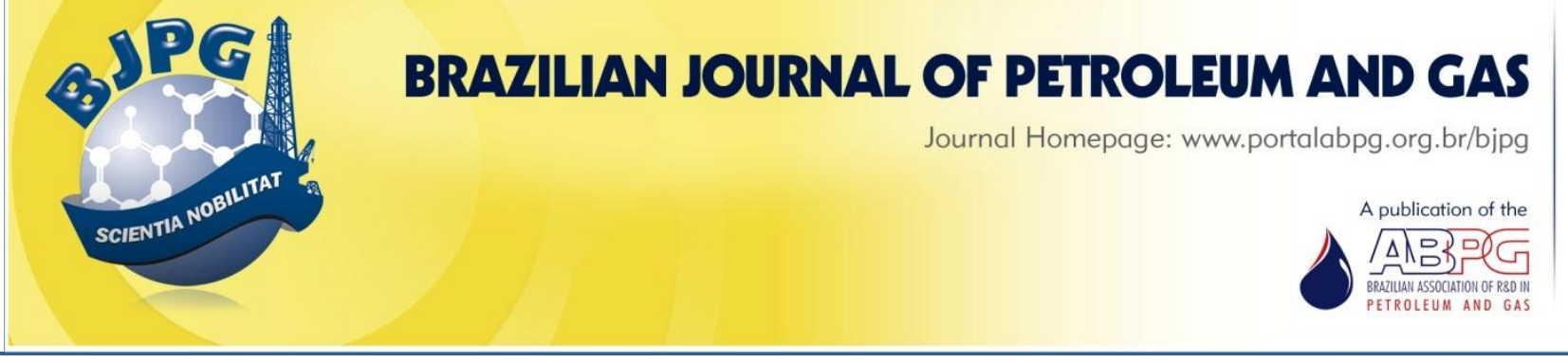

\title{
EMULSION INVERSION OF CRUDE OIL BY SOLID PARTICLE AND SURFACTANT ADDITION
}

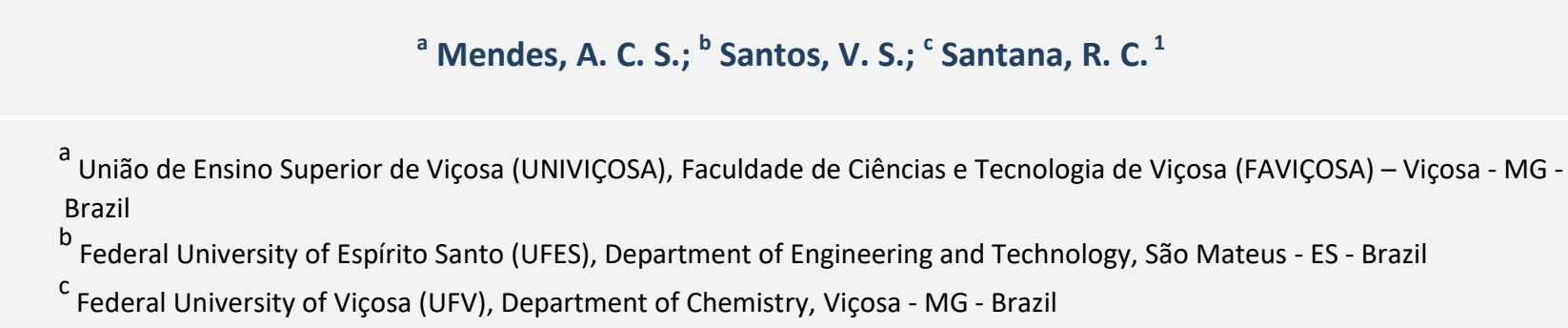

Received: 25.10.2018 / Revised: 26.02.2019 / Accepted: 07.03.2019 / Published on line: 03.04.2019

\begin{abstract}
Crude oil produced as water-in-oil (W/O) emulsion can show high viscosity, causing difficulties during pipeline transportation. The production of $\mathrm{O} / \mathrm{W}$ emulsion by adding an aqueous phase containing solid particles and surfactant is an alternative to decrease oil viscosity. Thus, the objective of this work is to study the synergistic effect of a surfactant (Triton X-100) and a solid particle (sodium bentonite) addition on emulsion inversion. Emulsions were characterized in conductivity, rheology, kinetic stability, and droplet size analyses. W/O to $\mathrm{O} / \mathrm{W}$ emulsions inversion occurred when aqueous solutions were between 30 and $40 \%(\mathrm{~m} / \mathrm{m})$, according to conductivity and rheology analyses. The increment of water content from 30 to $50 \%(\mathrm{w} / \mathrm{w})$ increased mean droplet size from 2.6 to $10.6 \mu \mathrm{m}$, increased phase separation from 9.5 to $68.0(\mathrm{v} / \mathrm{v})$, and decreased emulsion viscosity from 183 to $1.07 \mathrm{mPa}$.s. Aqueous solution containing solid particle and surfactant affected emulsions' properties, producing systems with lower viscosity than crude oil, making it easier for oil pumping and pipeline transportation.
\end{abstract}

\section{KEYWORDS}

petroleum; sodium bentonite; Triton-X-100; pipeline transportation; rheology

\footnotetext{
${ }^{1}$ To whom all correspondence should be addressed.

Address: Federal University of Viçosa (UFV), Department of Chemistry, Avenida Peter Henry Rolfs, Viçosa, MG, Brazil. ZIP Code: 36570-000 | Phone/Fax: + (55) (31) 38994987 / + (55) (31) 38993065 | e-mail: rejanecastro@gmail.com doi:10.5419/bjpg2019-0004
} 


\section{INTRODUCTION}

Petroleum is produced naturally as water-in-oil (W/O) emulsion, a system composed of water droplets dispersed in an oil continuous phase. Water and oil mixtures typically present in the reservoir pass over chokes and valves, and mechanical input leads to form water droplets. The emulsion is, then, stabilized by natural surfactants such as asphaltenes and resins (Hasan et al., 2010; Santana et al., 2017).

W/O emulsions can present higher viscosity than dehydrated oil. Emulsion viscosity depends on oil and water content, temperature, shear rate, droplet size distribution, and amount of solids in the crude oil (Kokal, 2005; Meriem-Benziane et al., 2012). Oil pumping operations occur at a typical shear rate of $500 \mathrm{~s}^{-1}$ (Santos et al., 2011), and the viscosity required for transport is limited to 0.25 and 0.40 Pa.s at $37.8^{\circ} \mathrm{C}$ (Muñoz et al., 2016). Oil emulsions with $0.40 \mathrm{mPa}$.s may be attained only with $25-30 \% \mathrm{w} / \mathrm{w}$ water content. Above $30 \%$ of water in emulsion, the viscosity may become too high (Martinez-Palou et al., 2011). Different methods are used to reduce oil viscosity for pipeline transportation, including dilution with light oils or alcohols, heating, use of emulsion viscosity reducers, and use of surfactants to stabilize oil-inwater (O/W) emulsions (Hasan et al., 2010; Santos et al., 2017).

Many authors suggest the use of surfactants for O/W emulsification (Pilehvari et al., 1988; Ashrafizadeh \& Kamran, 2009; Hasan et al., 2010; Abdurahman et al., 2012; Plasencia et al., 2013). In this method, the oil phase becomes dispersed in the water phase and stable $\mathrm{O} / \mathrm{W}$ emulsions are formed with the aid of suitable surfactants. O/W emulsions showed a significant reduction in system viscosity, with values in the range of approximately 0.05 and 0.2 Pa.s. Determining the viscosity is important for establishing the dimensions of pipeline and equipment (Salager et al., 2001; Abdurahman et al., 2012; Plasencia et al., 2013).

Surfactants are amphyphilic molecules that reduce the interfacial tension between crude oil and water, stabilizing droplets. O/W emulsions produced using surfactants should be stable during pipeline transportation. These $\mathrm{O} / \mathrm{W}$ emulsions should be easily broken before oil refining in order to separate the water to be treated from water discharge or recycling, requiring a minimal quantity of surfactant and other additives (Hasan et al., 2010; Martínez-Palou et al., 2011).

The main difficulties related to the use of this technology are the selection of surfactant and reduction of the costs associated with the selection (Hasan et al., 2010). Non-ionic surfactants are cheap and they are not affected by water salinity. Triton X-100 (polyethylene glycol octylphenyl ether) has a chemical formula of $\mathrm{C}_{33} \mathrm{H}_{60} \mathrm{O}_{10}$. It is a non-ionic surfactant used in $\mathrm{O} / \mathrm{W}$ emulsification of crude oil to reduce oil viscosity. Authors such as Abdurahman et al. (2012) and Hasan et al. (2010) have evaluated its use in the reduction of viscosity.

Solid particles can also be added in order to produce $\mathrm{O} / \mathrm{W}$ emulsion, adjusting its viscosity and stability (Souza, 2012). Solid particles act in wateroil interface due to their mutual affinity to oil and water, which depends on both the contact angle of particle and the water cut (Luz et al., 2008; Kralova et al., 2011). Particle contact angles ( $\theta$ measured through the aqueous phase) slightly below $90^{\circ}$ result in $\mathrm{O} / \mathrm{W}$ emulsions; when $\theta$ is slightly above $90^{\circ} \mathrm{W} / \mathrm{O}$ emulsions are formed. Conditions giving extreme contact angles (close to $0^{\circ}$ or $180^{\circ}$ ), no stable emulsions are formed. Its efficiency on stabilizing $\mathrm{W} / \mathrm{O}$ or $\mathrm{O} / \mathrm{W}$ emulsions depends on particle concentration, wettability, inter-particle interactions, particle shape, and size. A particle should be typically limited to a few micrometers in size, and it must be much smaller than the emulsion droplet size (Tambe \& Sharma, 1993).

Solid particles, as sodium bentonite, silica, and kaolinite nanoparticles have been used on catastrophic phase inversion for emulsions. This means that $\mathrm{W} / \mathrm{O}$ to $\mathrm{O} / \mathrm{W}$ emulsion transition happens with the addition of a water solution (Kralova et al., 2011; Souza et al., 2012). Bentonite is a hydrophilic material used widely in the industrial sector. It is formed mainly of clay minerals from the montmorillonite group with adsorbed cation sodium (Souza, et al. 2012).

Surfactant and solid particle can show a synergistic effect when added to petroleum emulsions. Wang et al. (2004) reported that kalonite particles are attracted by opposite charges of surfactants (anionic palmitic acid and cationic dodecyl amine) and they are adsorbed onto oilwater interface. In addition, surfactant addition to $\mathrm{O} / \mathrm{W}$ emulsions stabilized by kaolinite cause an 
interfacial surface tension decrease. On oil-brine emulsions composed of solid particles (barium sulphate, calcium carbonate, and silica), the synergistic effect was attributed to the increase of particle contact angle on adsorption when surfactant stearic acid is added. However, high surfactant concentration can compete for active sites on the oil-water interface, inhibiting particle adsorption and decreasing emulsion stability (Tambe \& Sharma, 1993, 1994a, 1994b; Hunter et al., 2008). Similar results were observed on the work of Gosa and Uricanu (2002) analyzing systems composed of silica and PEO-PPO-PEO block copolymers. Instability phenomena increased due to flocculation of silica with surfactant adsorption.

The proposed study evaluates the synergistic effect of surfactant and solid particle on crude oilin-water emulsification in the production of low viscous emulsions. This study evaluates the conductivity, kinetic stability, rheology, and droplet size of $\mathrm{W} / \mathrm{O}$ and $\mathrm{O} / \mathrm{W}$ emulsions at different water solution concentrations (30, 40, and $50 \% \mathrm{w} / \mathrm{w}$ ) containing bentonite particle $(0.5 \% \mathrm{w} / \mathrm{w})$ and Triton-X-100 (1.0\% w/w).

\section{MATERIALS AND METHODS}

\subsection{Materials}

Crude oil sample was obtained from a field located in Brazil. It was used without previous treatment in the production of petroleum emulsions. Crude oil shows $75.7 \mathrm{mPa}$.s at $100 \mathrm{~s}^{-1}$ (Pena et al., 2018). Triton-X-100 (Neon, Brazil) and sodium bentonite with particle size smaller than 44 $\mu \mathrm{m}$ (Proquímicos, Brazil) were used to produce emulsions.

\subsection{Emulsion preparation}

Emulsions composed of crude oil $(70,60$, and 50 $\% \mathrm{w} / \mathrm{w})$ and aqueous solution $(30,40$, and $50 \%$ $\mathrm{w} / \mathrm{w}$ ) were produced in an Ultra-Turrax T25 (IKA, Germany), at $15000 \mathrm{rpm} / 2 \mathrm{~min}$.

Initially, an aqueous phase was prepared using distilled water. Surfactant Triton-x-100 (1\% w/w) and sodium bentonite $(0.5 \% \mathrm{w} / \mathrm{w})$ were weighted and the aqueous solution was magnetically stirred for 2 minutes prior to the emulsion preparation at rotor-stator device. Solid particle concentration was previously defined according to a study conducted by Pena et al. (2018). The required amount of the crude oil was added gradually into the aqueous phase, and the mixing formed the emulsion. Afterwards, the emulsion was taken for conductivity, stability, and optical microscopy measurements. All preparations and measurements were conducted at room temperature $\left(25^{\circ} \mathrm{C}\right)$ and in triplicate.

\subsection{Emulsion characterization}

\subsubsection{Conductivity}

Electric conductivity of emulsions was evaluated immediately after homogenization process in a conductimeter W12D (BEL Engineering, Italy).

\subsubsection{Kinetic stability}

The emulsions prepared were tested for stability by transferring the emulsions into $50 \mathrm{~mL}$ capacity graduated cone-shaped glass tubes, with $0.1 \mathrm{~mL}$ graduations. The phase separation was registered for 7 days at room temperature.

\subsubsection{Optical microscopy and droplet size distribution}

The microstructure of the emulsions was studied immediately after homogenization process using an optical microscopy (Leica, Germany). The samples were poured onto microscope slides, covered with glass cover slips, and observed at a magnification of 40x. At least 10 images were taken for each sample, and the best 5 sharp pictures were analyzed using the public domain software Image J 1.50i (ImageJ, 2017). Micrographs of the emulsions were analyzed by measuring the diameter of at least 500 droplets (one by one) (Santana et al., 2011). After conversion of the pixel-scale into microns by a scaling factor, droplet diameter data were used to plot a histogram of droplet frequency (number percentage) versus droplet size category. Considering spherical droplets, the surface mean diameter $\left(d_{32}\right)$ of the emulsions were calculated as $d_{32}=\Sigma\left(n_{i} d_{i}^{3}\right) / \Sigma\left(n_{i} d_{i}^{2}\right)$, where $n_{i}$ is the number of particles with diameter $\mathrm{d}_{\mathrm{i}}$. 
Table 1. Kinetic stability of emulsions with 30, 40, and 50\% (w/w) water at different periods (1 hour, 1 day, and 7 days).

\begin{tabular}{cccc}
\hline & \multicolumn{3}{c}{ Volume $(\mathrm{ml})$ of aqueous phase separation } \\
\cline { 2 - 4 }$\%(\mathrm{w} / \mathrm{w})$ water & 1 hour & 1 day & 7 days \\
\hline $30 \%$ & 8.50 & 9.50 & 9.50 \\
$40 \%$ & 26.3 & 41.3 & 42.3 \\
$50 \%$ & 56.0 & 67.3 & 68.0 \\
\hline
\end{tabular}

\subsubsection{Rheology}

Rheological measurements of the emulsions were carried out using a viscosimeter OFITE model 900 (United States). The samples were analyzed immediately after homogenization process. Steady shear measurements were made in triplicate at 25 ${ }^{\circ} \mathrm{C}$. Flow curves were obtained using an up-downup step program using a shear rate range between 0 and $300 \mathrm{~s}^{-1}$.

\section{RESULTS AND DISCUSSIONS}

\subsection{Conductivity}

Electric conductivity is affect by water content and by dispersed phase size. Emulsion inversion from W/O or O/W type can be identified by conductivity measurements, since W/O emulsions show low conductivity values, while O/W emulsions show high conductivity values (Schramm, 1992).
Emulsions conductivity values (Figure 1) increased when the water content increased from 30 to $40 \%(w / w)$ of water, suggesting an emulsion inversion (W/O to $\mathrm{O} / \mathrm{W}$ emulsion) in water concentration range. Phase inversions between 30 and $40 \%(\mathrm{w} / \mathrm{w})$ of water were also observed by Pena et al. (2018) in emulsions composed by the same crude oil and solid particle (without surfactant addition), and by Bento et al. (2015) in emulsions composed by Tween 80, a hydrophilic non-ionic surfactant as Triton-X-100. The same authors also observed phase inversion at higher water contents (60 and $90 \% \mathrm{w} / \mathrm{w}$, depending on oil phase and temperature) when a Span 60 was used. The hydrophobic surfactant tends to form W/O emulsion in a larger range of water compositions.

\subsection{Kinetic Stability}

The percentages of aqueous phase separated from the emulsions after 1 hour, 1 day, and 7 days of storage are shown in Table 1 . The phase separation was faster in the first hour, and it continued increasing up to 7 days of storage. The

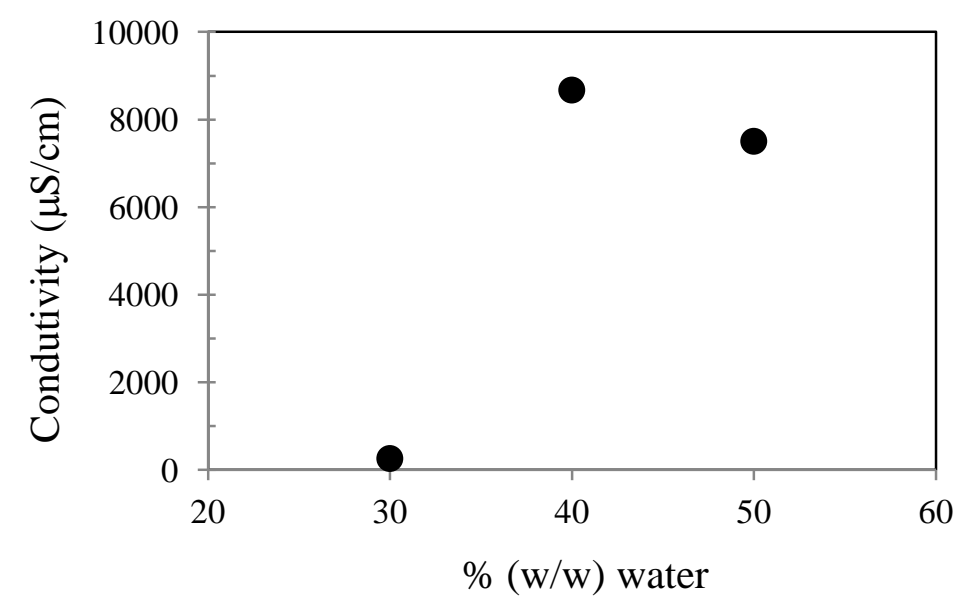

Figure 1. Conductivity $(\mu \mathrm{S} / \mathrm{cm})(\bullet)$ of emulsions with 30,40 , and $50 \%(w / w)$ of water. 


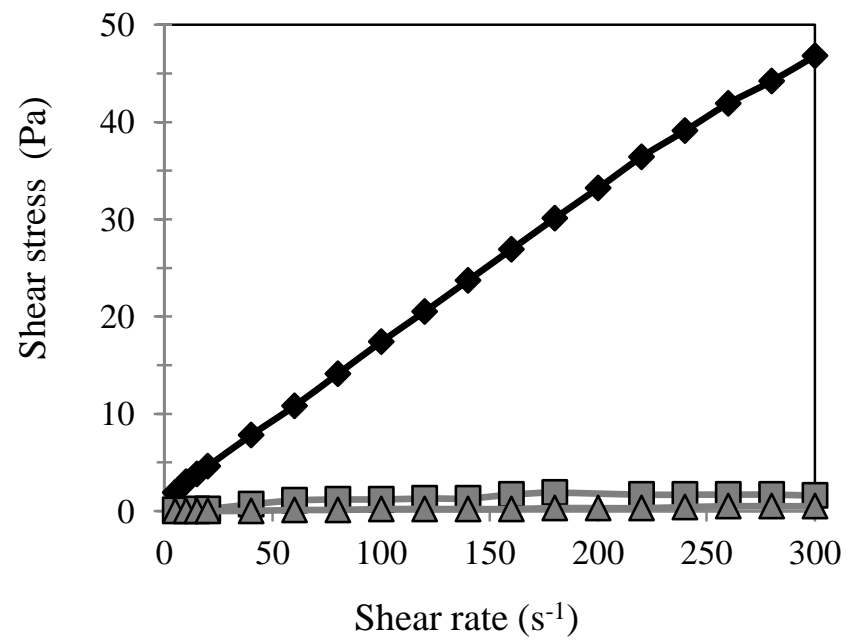

Figure 2. Flow curves of emulsions with $30(\diamond), 40(\square)$, and $50 \%(w / w)(\Delta)$ of water.

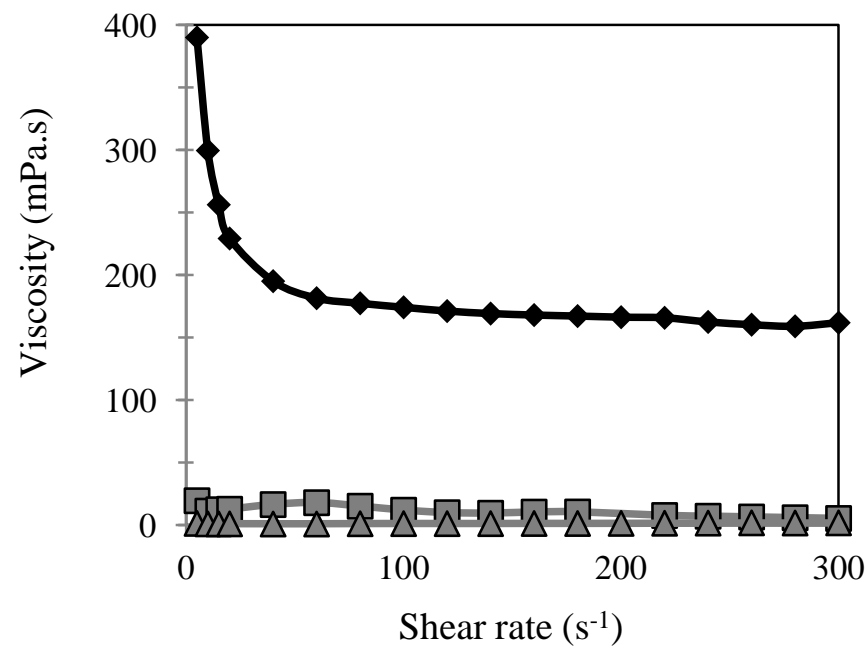

Figure 3. Viscosity of emulsions with $30(\bullet), 40(\square)$, and $50 \%(w / w)(\Delta)$ of water.

emulsion with $30 \%(w / w)$ of water showed high kinetic stability, with only $9.50 \%(\mathrm{v} / \mathrm{v})$ of separation. This behavior can be explained by the emulsion type $(\mathrm{W} / \mathrm{O})$ identified on conductivity measurements. Moreover, this emulsion had lower water content if compared to other emulsions. The increment of water to 40 and $50 \%(\mathrm{w} / \mathrm{w})$ increased emulsion instability to 42 and $68 \%(\mathrm{v} / \mathrm{v})$ of phase separation, respectively.

\subsection{Rheology}

Flow curves and viscosities results for the studied emulsions are shown in Figures 2 and 3. Emulsions with 30 and $50 \%(\mathrm{w} / \mathrm{w})$ water showed a
Newtonian behavior, while emulsion with $40 \%$ $(\mathrm{w} / \mathrm{w})$ showed a non-Newtonian behavior. Emulsion viscosities decreased significantly with water content increment. Emulsions with $30 \%$ $(\mathrm{w} / \mathrm{w})$ of aqueous phase showed a higher viscosity (183 mPa.s at $100 \mathrm{~s}^{-1}$ ) if compared to crude oil (75.7 mPa.s, at $100 \mathrm{~s}^{-1}$ ) (Pena et al., 2018), indicating that this system is a W/O emulsion, in agreement with conductivity results. Emulsion inversion occurred between 30 and $40 \%(w / w)$ of water, since emulsions with 40 and $50 \%(\mathrm{w} / \mathrm{w})$ of aqueous phase showed reduced viscosity $(6.33 \mathrm{mPa} . \mathrm{s}$ and 1.07 mPa.s, respectively) (Ashrafizadeh \& Kamran, 2009), with lower values than emulsions composed by the same crude oil and solid particle, in absence of surfactant (Pena et al., 2018). Abdurahman et 


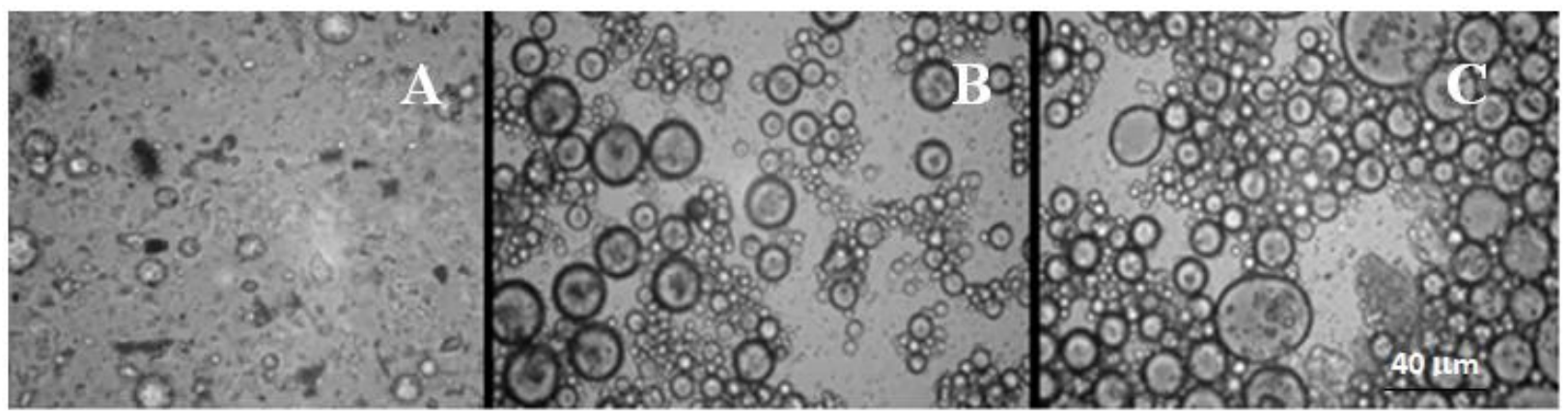

Figure 4. Optical microscopy of emulsion with 30 (A), 40 (B), and $50 \%$ (w/w) (C) of water.
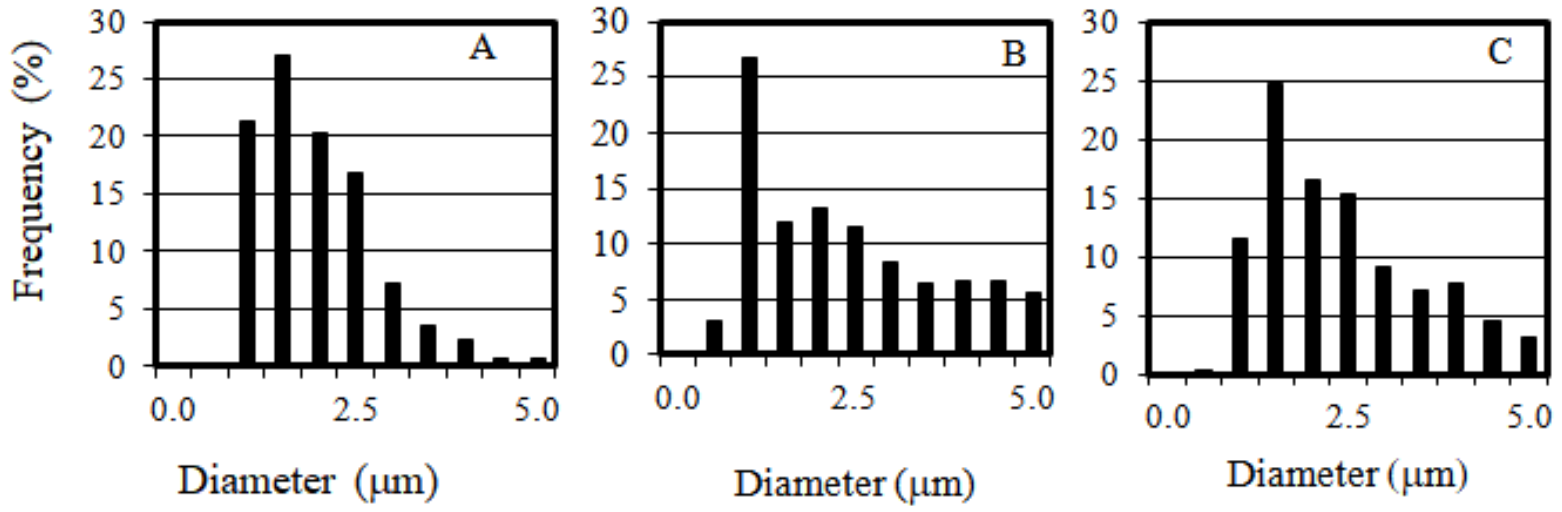

Figure 5. Droplet size distribution of emulsions with $30 \%(A), 40 \%(B)$, and $50 \%(C)(w / w)$ of aqueous solution.

al. (2012) showed that the use of Triton-X-100 changed the properties of $72 \% \mathrm{v} / \mathrm{v}$ crude oil emulsions, prepared at $1700 \mathrm{rpm} / 15 \mathrm{~min}$, in absence of solid particles, at $30^{\circ} \mathrm{C}$. Emulsions with a slight increase in the viscosity and a significant increase in stability were produced with the increment of Triton concentration from 0.0125 to $1.5 \%(w / w)$.

\subsection{Microstructure and mean droplet size}

Figure 4 shows an emulsion microstructure, while Table 2 and Figure 5 present mean droplet size $\left(d_{32}\right)$ and droplet size distribution, respectively.
Mean droplet size increased with water increment, varying between 2.8 and $10.6 \mu \mathrm{m}$. In addition, the increment of water content produced emulsions with a higher polidispersity, and a higher frequency of droplets bigger $2.5 \mu \mathrm{m}$. One can also note that the emulsions with bigger droplet size showed lower viscosity and worst kinetic stability. These are desired properties to pipeline transportation and posterior water separation at the end of this process. Bigger droplet size and higher kinetic instability of emulsion with 40 and $50 \%(\mathrm{w} / \mathrm{w})$ will turn easy emulsion destabilization during primary treatment.

Table 2. Mean droplet size $\left(d_{32} / \mu \mathrm{m}\right)$ of emulsions with different water concentration.

\begin{tabular}{cc}
\hline$\%(w / w)$ of water & $d_{32}(\mu \mathrm{m})$ \\
\hline 30 & $2.80 \pm 0.870$ \\
40 & $6.29 \pm 1.59$ \\
50 & $10.6 \pm 1.29$ \\
\hline
\end{tabular}




\section{CONCLUSIONS}

Emulsion inversion was confirmed by the evaluation of all emulsion properties. W/O to O/W emulsion occurred between 30 and $40 \%(\mathrm{w} / \mathrm{w})$ of aqueous phase. The emulsion with $30 \%(\mathrm{w} / \mathrm{w})$ water showed low conductivity and high viscosity. High viscosity is associated with continuous phase composed by oil. Moreover, the emulsion with $30 \%$ $(\mathrm{w} / \mathrm{w})$ water showed small droplet size and, consequently, high kinetic stability. On the other hand, emulsions with 40 and $50 \%(\mathrm{w} / \mathrm{w})$ water showed high conductivity, low viscosity, bigger droplet size, and lower kinetic stability. Solid particle and surfactant addition affect emulsion properties, inducing emulsion inversion and producing $\mathrm{O} / \mathrm{W}$ emulsion with lower viscosity than crude oil, attaining adequate conditions to pipeline transportation of petroleum emulsions when using 40 or $50 \%(w / w)$ water.

\section{ACKNOWLEDGMENTS}

The authors would like to recognize FAPES (Fundação de Amparo à Pesquisa e Inovação do Espírito Santo, Brazil) for the financial support for this study.

\section{REFERENCES}

Abdurahman, N. H.; Rosli, Y. M.; Azhari, N. H.; Haycler, B. A. Pipeline transportation of viscous crudes as concentrated oil-in-water emulsions. Journal of Petroleum Science and Engineering, v. 90-91, p.139-144, 2012.

https://doi.org/10.1016/i.petrol.2012.04.025

Ashrafizadeh, S.N.; Kamran, M. Emulsification of heavy crude oil in water for pipeline transportation. Journal of Petroleum Science and Engineering, v. 71, p.205-211, 2009.

https://doi.org/10.1016/j.petrol.2010.02.005

Bento, J. J.; Guth, M.; Weinschutz, R.; Yamamoto, C.I.; Luiz Junior, L. F. de L. Estudo da inversão catastrófica em emulsões de petróleosistema modelo. XX Congresso Brasileiro de Engenharia Química - COBEQ 2014, Blucher Chemical Engineering Proceedings, v.1, n.2, p. 5266-5273, 2015.

https://doi.org/10.5151/chemeng-cobeq2014-0120$\underline{26939-157556}$
Gosa, K-L.; Uricanu, V. Emulsions stabilized with PEO-PPO-PEO block copolymers and silica. Colloids and Surface A: Physicochemical and Engineering Aspects, v. 197, p. 257-269, 2002. https://doi.org/10.1016/S0927-7757(01)00902-5

Hasan, S. W.; Ghannam, M. T.; Esmail, N. Heavy crude oil viscosity reduction and rheology for pipeline transportation. Fuel, v. 89(5), p. 10951100, 2010. https://doi.org/10.1016/i.fuel.2009.12.021

Hunter, T. N.; Pugh, R. J.; Frnaks, G. V.; Jameson, G. J. The role of particles in stabilizing foams and emulsions. Advances in Colloid and Interface Science, v. 137, p. 57-81, 2008.

https://doi.org/10.1016/i.cis.2007.07.007

ImageJ. Image Processing and Analysis in Java. Available at: <http://rsb.info.nih.gov/ij/>. Accessed on: 01/06/2017.

Kokal, S. L. Crude-oil emulsions: A state-of-theart review. SPE Production \& Facilities, v. 20 (10), p. 5-13, SPE 77497-PA, 2005. https://doi.org/10.2118/77497-PA

Kralova, I.; Sjoblom, J.; Oye, G.; Simon, S.; Grime, B. A.; Paso, K. Heavy Crude Oils/Particle Stabilized Emulsions. Advances in Colloid and Interface Science, v. 169, p. 106-127, 2011. https://doi.org/10.1016/i.cis.2011.09.001

Luz, A. P.; Ribeiro, S.; Pandolfelli, V. C. Uso da molhabilidade na investigação do comportamento de corrosão de materiais refratários. Cerâmicas, São Carlos, v. 54, p. 174-183, 2008. (In Portuguese)

Martinez-Palou, R.; Mosqueira, M. L.; ZapataRendón, B.; Mar-Juárez, E; Bernal-Huicochea, C.; Clavel-López, J. C.; Aburto, J. Transportation of heavy and extra-heavy crude oil by pipeline: $A$ review. Journal of Petroleum Science and Engineering, v. 75, p. 274-282, 2011.

https://doi.org/10.1016/i.petrol.2010.11.020

Meriem-Benziane, M.; Abdul-Wahab, S. A.; Benaicha, M.; Belhadri, M. Investigating the rheological properties of light crude oil and the characteristics of its emulsions in order to improve pipeline flow. Fuel, v. 95, p. 97-107, 2012. https://doi.org/10.1016/j.fuel.2011.10.007

Muñoz, J. A. D.; Ancheyta, J.; Castañeda, L. C. Required viscosity to ensure proper transportation of crude oil by pipeline. Energy \& Fuels, v. 30(11), p. 8850-8854, 2016.

https://doi.org/10.1021/acs.energyfuels.6b01908 
Pena, G. O.; Silva, C. A. S.; Santana, R. C. Crude oil-in-water emulsification using solid particle for pipeline transportation. The Journal of Engineering and Exact Science, v. 04, p. 59-64, 2018. https://doi.org/10.18540/icecvl4iss1pp0059-0064

Pilehvari, A.; Saadevandi, B.; Halvaci, M.; Clark, D. E. Pipeline transportation of heavy crudes as emulsions, In: Roco, M. C. (Ed.), Proc. 3rd Int. Symp. Liquid Solid Flows ASME, New York, 1988.

Plasencia, J.; Pettersen, B.; Nydal, O. J. Pipe flow of water-in-crude oil emulsions: Effective viscosity, inversion point and droplet size distribution. Journal of Petroleum Science and Engineering, v. 101, p. 35-43, 2013.

https://doi.org/10.1016/i.petrol.2012.11.009

Salager, J. L.; Briceño, M. A.; Brancho, C. L. Heavy hydrocarbon emulsions. Making use of the state of the art in formulation engineering. In: Sjöblom, J. (Ed.), Encyclopedic Handbook of Emulsion Technology. New York: Marcel Dekker, Chap. 20, p. 455-495, 2001.

Santana, R. C.; Silva, C. A. S.; Beraldo, C. S. Emulsões de Petróleo, 1a Ed., OmniScriptum Publishing Group, Beau Bassin, 42p., 2017.

Santana, R. C.; Perrechil, F. A.; Sato, A. C. K.; Cunha, R. L. Emulsifying properties of collagens fibers: Effect of $\mathrm{pH}$, protein concentration and homogenization pressure. Food Hydrocolloids, v. 25, p. 604-612, 2011.

https://doi.org/10.1016/i.foodhyd.2010.07.018

Santos, R. G.; Bannwart, A. C.; Briceño, M. I.; Loh, W. Physico-chemical properties of heavy crude oil-in-water emulsions stabilized by mixtures of ionic and non-ionic ethoxylated nonyphenol surfactants and medium chain alcohols. Chemical Engineering Research and Design, v. 89, p. 957967, 2011.

https://doi.org/10.1016/i.cherd.2010.11.020
Santos, I. C. V. M.; Oliveira, P. F.; Mansur, C. R. E. Factors that affect crude oil viscosity and techniques to reduce it: a review. Brazilian Journal of Petroleum and Gas, v.11, p. 115-130, 2017. https://doi.org/10.5419/bjpg2017-0010

Schramm, L. L. Emulsions, Fundamentals and Applications in the Petroleum Industry. Washington: American Chemical Society, Advances in Chemistry Series: 231, 1992.

Souza, T. A. Scheer, A. P.; Khalil, M. C.; Yamamoto, C. I.; Luz Jr., L. F. L. Emulsion inversion using solid particles. Journal of Petroleum Science and Engineering, v. 96-97, p. 49-57, 2012. https://doi.org/10.1016/j.petrol.2012.08.008

Tambe, D. E.; Sharma, M. M. Factors controlling the stability of colloid-stabilized emulsions: I. An experimental investigation. Journal of Colloid Interface, v. 157, p. 244-53, 1993.

https://doi.org/10.1006/icis.1993.1182

Tambe, D. E.; Sharma, M. M. Factors controlling stability of colloid-stabilized emulsions: II. A model for the rheological properties of colloid-Laden interfaces. Journal of Colloid Interface, v. 162, p. 1-10, 1994a.

https://doi.org/10.1006/jcis.1994.1001

Tambe, D. E.; Sharma, M. M. The effect of colloidal particles on fluid-fluid interfacial properties and emulsion stability, Advances in Colloid Interface Science, v. 52, p. 1-63, 1994b. https://doi.org/10.1006/icis.1994.1001

Wang, W.; Zhou, Z.; Nandakumar, K.; Xu, Z.; Masliyah, J. H. Effect of charged colloidal particles on adsorption of surfactants at oil-water interface. Journal of Colloid Interface Science, v. 274, p. 625630, 2004. https://doi.org/10.1016/j.jcis.2004.03.049 